\title{
Mutagenesis and inter-specific protoplast fusion between Trichoderma koningii and Trichoderma reesei for biocontrol improvement
}

\author{
Hassan Abdel-Latif A. Mohamed ${ }^{1 \& 3}$ and Wafaa Mohamed Haggag ${ }^{2}$ \\ ${ }^{1}$ Department of Microbial Genetics, National Research Centre, Dokki, Cairo, Egypt. \\ ${ }^{2}$ Department of Plant Pathology, National Research Centre, Dokki, Cairo, Egypt, \\ ${ }^{3}$ Corresponding author. P.O. Box 12311,Tel. 002-02-33335983; Exo. 1568 (Dept.), Fax: 002- \\ 02-33370931, Tel. 002-0124495804(mobile); E-mail: habedlltif@yahoo.com
}

\begin{abstract}
The present work aimed to apply mutagenesis and inter-specific protoplast techniques of two locally isolated Trichoderma spp. to enhancement their biocontrol abilities against some important plant fungal pathogens which cause root-rot and damping-off diseases that attacking different crops. A combination of UV-light and nitrate treatment induced seven mutants ( $T$. koningii, 3 mutants and $T$. reesei, 4 mutants). The inter-specific protoplast fusion between $T$. koningii and $T$. reesei gave fusion frequency reached $1.25 \%$ and thirteen fusants were isolated. In vitro bioassay of the parental Trichoderma spp., their selected mutants and fusants indicated the effective of both $T$. koningii and $T$. reesei in suppressive the tested fungal pathogens. On the other hand, most of the selected mutants and fusants showed superiority in their antagonistic activity against these pathogens than their parental strains. the superiority in biological control activities of the selected mutants or fusants than their parents against the tested pathogens may be due to the effect of the genetic treatments (i.e. mutagenesis an protoplasts fusion) on their genetic back ground to be varied that allow to change in genetic control of antifungal metabolites production to be more effective. The results indicated that mutation and protoplast fusion techniques are successful tools to enhance the antagonistic effects of Trichoderma species against several fungal plant pathogens.
\end{abstract}

Keywords: Biological control, plant pathogens, mutation, protoplast fusion.

\section{INTRODUCTION}

Several microorganisms e.g., bacteria, actinomycetes, yeasts and different genus of fungi especially Trichoderma spp produce many types of antifungal metabolites [1].

Biological control of several plant pathogens showed promise as an option diseases management strategy [2]. Antagonistic microorganisms represent the most diverse group of organisms on the plant. Even through the natural microflora, antagonistic fungi included Trichoderma and Gliocladum species are surmised of special share as biological control agents against numerous phytopathogenic fungi [2]. Trichoderma or Gliocladum species are known as cogent producer of many antifungal metabolites including enzymes, antibiotics and others [3 - 5].

Mutagenesis or protoplast fusion of biocontrol agents were applied to improve the antifungal production and antagonistic potential over a broad spectrum of phytopathogens, survival, longevity and activity ([6 13]. Protoplast fusion is a quick and easy method for combining the advantageous properties of distinct promising strains. It was successfully applied in the breeding of $T$. harzianum biocontrol strains $[14,15]$. Protoplasts could be produced easily from biocontrol Trichoderma strains and their induced fusion resulted in genetic recombinants with elevated biocontrol abilities in many instances [16].

The present work aimed to apply mutagenesis and inter-specific protoplast fusion techniques of two locally isolated Trichoderma spp. to enhancement their biocontrol abilities against some of important plant fungal pathogens which cause root-rot and damping-off diseases that attacking different crops growing either in open field or in greenhouses.

\section{MATERIALS AND METHODS}

\section{Strains}

Bioagents: Two locally Trichoderma species, $T$. koningii and $T$. reesei [17] were kindly obtained from Prof. Dr. Mohamed Fadel, Microbiological Chemistry, NRC, and Egypt.

Pathogens: Four fungal pathogens; Fusarium oxysporum, [18], Pythium ultimum [19], Sclerotia 
rolfsii and Sclerotinia sclerotiorum [13] the causal fungi of root-rot, damping-off and wilt diseases, were isolated from diseased plants, from south Giza (Gezerit El-Dahab) and El-Bohira (Noubaria districts), Egypt and identified in Plant Pathology Department, NRC, Dokki, Cairo, Egypt.

Fungi cultures were maintained on Potato Dextrose agar (PDA) medium. Minimal agar medium (MM) was used to test the auxotrophic characters, Dextrose Broth (PDB) medium or Czapek Dox Salt solution (CDS) were used to obtain the fungal culture filtrates [12].

Mutation Induction and Isolation: The mutants were obtained from Trichoderma spp. according to the methods of [8] with slightly modifications. The parent strains; $T$. koningii and $T$. reesei were grown on PDA slants at $30^{\circ} \mathrm{C}$ to induce sporulation. One week after sub-culturing conidial suspension was prepared by dislodging the conidia from the agar surface with a sterile needle to a sterile glass vial and by pouring sterilized physiological saline $(0.85 \%$ $\mathrm{NaCl}$ ) containing $0.1 \%$ Tween-80 to disperse spore clumps. The prepared conidial suspension was divided to two portions in two sterilized small glass vials. Conidial concentrations were adjusted to $\approx 10^{6} /$ $\mathrm{ml}$. The first glass vial was used as control. The second glass vial was treated with $500 \mu \mathrm{g} / \mathrm{ml}$ sodium nitrate $\left(\mathrm{NaNO}_{2}\right)$ and was irradiated for 80 min under ultraviolet lamp (GERMICIDAL LAMP (VL-G), UVtube T-15C 15W $254 \mathrm{~nm}$, VILBER-LOURMAT) where the distance between the agar surface and the lamp was adjusted to $30 \mathrm{~cm}$. After irradiation the conidial suspensions were incubated at $30^{\circ} \mathrm{C}$ for $45-60 \mathrm{~min}$ in dark. After incubation period $0.1 \mathrm{ml}$ was poured on the solidified Czapek-Dox mineral medium supplemented with $0.1 \%$ Triton $\mathrm{X}-100$ to restrict the growth of the fungal colonies [8]. The plates were incubated at $30^{\circ} \mathrm{C}$ for 6 days until the fungal colonies were observed.

The surviving colonies were tested on $\mathrm{MM}$ to eliminate auxotrophic colonies. The colonies appeared on MM were selected and examined for some characters including growth rate that measured as linear growth $(\mathrm{mm})$, sporulation that counted as colony forming unit (cfuX10) according to [12] and their antagonistic effects against Pythium ultimum. The isolates, which displayed better characters than its parent isolates, were isolated and sub-cultured 7 times on PDA to test their stability. Those isolate which retained the altered characteristics were identified as mutants and designated as (Tk-UVN-No. or Tr-UVN-No.

\section{Protoplast Fusion:}

Behavior resistance of the bioagents on different antifungal agents: The parental strains; $T$. koningii and $T$. reesei were streaked on the surface of malt extract agar plates supplemented with specific antifungal agents (Benomyl, Cyclohexamide, Hygromycin, Micanazol and Nystatin) with the doses of $30,76,1,60$ and $100 \mu \mathrm{g} / 50 \mathrm{ml}$ medium, respectively were used to determine the fungal resistant behavior, and incubated for 7 days at $30^{\circ} \mathrm{C}$. Then, their resistance behavior was recorded.

Protoplasting medium (PM) or (Regeneration medium): The medium of [20] was used for pregrowing fungal strains for protoplasting, contains $\mathrm{g} \mathrm{L}^{-}$ $\left.{ }^{1}\right)$ : glucose, $80 ; \mathrm{NH}_{4} \mathrm{NO}_{3}, 2 ; \mathrm{KH}_{2} \mathrm{PO}_{4}, \quad$ 10; $\mathrm{MgSO}_{4} .7 \mathrm{H}_{2} \mathrm{O}, 0.25 ; \mathrm{FeCl}_{3} .6 \mathrm{H}_{2} \mathrm{O}, 0.02$ and $\mathrm{MnSO}_{4}$, 0.014 at an initial $\mathrm{pH}$ of 4.5 .

Protoplasting buffer (PB): The parental isolates were inoculated in PB buffer consists of phosphate buffer $(0.1 \mathrm{M}, \mathrm{pH} 5.8-6)$ containing $0.7 \mathrm{M} \mathrm{NaCl}, 0.2$ $\mathrm{M} \mathrm{CaCl} 2$ and Novozyme $234\left(20 \mathrm{mg} \mathrm{mL}^{-1}\right)$ and incubated at $30^{\circ} \mathrm{C}$ with gentle shaking for up to $6 \mathrm{~h}$.

Fusion buffer (FB): The buffer of FB consists of phosphate buffer $(0.05 \mathrm{M}, \mathrm{pH} 7.5)$ containing $30 \%$ (w/v) polyethylene glycol (PEG) 6000, $50 \mathrm{mM} \mathrm{CaCl}_{2}$ and $0.7 \mathrm{M} \mathrm{NaCl}$.

Selective medium (SM): The SM medium consists of; malt extract agar containing $0.7 \mathrm{M} \mathrm{NaCl}$ and supplemented with antifungal agents (Hygromycin and Micanazol).

Protoplast Formation: Spore suspension of each parent, T. koningii or $T$. reesei was inoculated in 50 $\mathrm{mL} P M$ and incubated for $36 \mathrm{~h}$ at $30^{\circ} \mathrm{C}$ on rotary shaker $(180 \mathrm{rpm})$. The mycelium formed was recovered by centrifugation (1340 $\mathrm{xg}$ for $10 \mathrm{~min}$ ), washed twice with sterilized physiological saline $(0.85$ $\% \mathrm{NaCl}$ ), and re-suspended in $5 \mathrm{~mL} \mathrm{~PB}$. The mixture was investigated by light microscope.

Inter-specific Protoplast Fusion: Equal volumes of crude protoplast suspension from the two parents ( $T$. koningii and $T$. reesei) were mixed and centrifuged (1340 $\mathrm{xg}$ for $10 \mathrm{~min}$ ). The protoplast pellet formed was re-suspended in $2 \mathrm{~mL}$ FB and incubated for 20 $\min$ at $30^{\circ} \mathrm{C}$.

Fusants Isolation: PEG-treated protoplast suspension was plated onto the surface of SM supplemented with antifungal agents (Hygromycin and Micanazol) and incubated for 7 days at $30^{\circ} \mathrm{C}$. 
Colonies growing on the surface of the plates were considered as fusants.

\section{Antagonistic effect of the Tested Bioagents Against the Tested Pathogens}

Dual culture on PDA medium: The tested Trichoderma species (parental or genetically modified) were examined for their antagonistic effect against the tested pathogens by inoculating the fungal discs on $90 \mathrm{~mm}$ diameter PDA plates near the periphery opposite to each other. Antagonistic activity was measured as growth reductions [18]. The growth of tested mutants and fusants were compared to the growth of their wild type strains as positive control and PDA medium as negative control.

Filtrate inhibition: The tested Trichoderma species (parental or genetically modified) were grown on CDS medium for 10 days at $30^{\circ} \mathrm{C}$ to obtain the fungal culture filtrates. The fungal filtrates were sterilized through a $0.45 \mu \mathrm{m}$ sterile milipore filter. Volume of each fungal filtrate was added to (2X) PDA medium to give final concentration of $50 \%$, and then inoculated with equal discs ( $5 \mathrm{~mm}$ in diam) of the tested pathogen. After incubation, colonies diameters were determined and antagonistic activity was measured as growth reduction compared to their growth on PDA alone [18].

Statistical Analysis : All treatments in the previous experiments consisted of three or more replicates. The obtained data were statistically computed using the software SPSS for Windows (release 9.0.0, Dec. 18, 1998, standard version, SPSS Inc.).

\section{RESULTS}

Combined mutagenic treatments: A combination of UV-light and sodium nitrate was used to mutagenized $T$. koningii and $T$. reesei conidia where about 96.54 and $91.10 \%$, respectively of the treated conidia had been killed (Fig. 1). Several colonies were tested after mutagenesis for their morphological or antagonisms differences. Three and four mutants were isolated from $T$. koningii and $T$. reesei strains, respectively (Table 1 ).
After 7 subcultures the tested isolates were fast growing. While, the selected mutants (Tk-UVN-1, TkUVN-2, Tk-UVN-3, Tr-UVN-1, Tr-UVN-2, Tr-UVN-3, Tr-UVN-4) covered the whole plates after incubation 4 days, compared to 6 days of the parent strains ( $T$. koningii and $T$. reesei). The same trend was verified for sporulation on PDA medium up to 6 days. The parent strains barely increased the spore count up to 6 days, and then declined. Among the seven mutant isolates, Tk-UVN-1, Tk-UVN-2, Tk-UVN-3, Tr-UVN-1, Tr-UVN-2, Tr-UVN-3, Tr-UVN-4 were especially high in spore count compared to the parent strains (Table 2).

Inter-specific Protoplast Fusion: Figure (2) shows free protoplasts (B and D) after lytic digestion of mycelia ( $A$ and $C$ ) of $T$. reesei and $T$. koningii, respectively. The antifungal agents (Benomyl, Cyclohexamide, Hygromycin, Micanazol and Nystatin) with the doses of $(30,76,1,60$ and $100 \mu \mathrm{g} /$ $50 \mathrm{ml}$ medium, respectively were used to determine the fungal resistant behavior. The results showed that $T$. koningii was sensitive to Benomyl and Hygromycin, whilst resistant to Cyclohexamide, Micanazol and Nystatin. On the other hand, T. reesei was sensitive to Benomyl and Micanazol whilst resistant to Cyclohexamide, Hygromycin, and Nystatin. So that Hygromycin and Micanazol were used as selective markers for the tow parental fusion.

Table (3) showed the efficiency of protoplast fusion between the two parents strains were fusion frequency reached $1.25 \%$.

\section{Antagonistic Activity}

\section{Antagonistic effects of selected mutants against the tested pathogens}

Data given in Table (4) showed that the wild type strain, $T$. koningii caused high reduction of Fusarium oxysporum growth while $T$. reesei produced a minute growth reduction. The mutants caused higher reduction rate ranged between $92.6 \%$ (Tk-UVN-2) to $\%$ (TrUVN-1) against $F$. oxysporum growth except the mutants Tk-UVN-3 and Tr-UVN-3 that showed $58.2 \%$ and $56.2 \%$, respectively. 
Am. J. Sci. Ind. Res., 2010, 1(3): 504-515

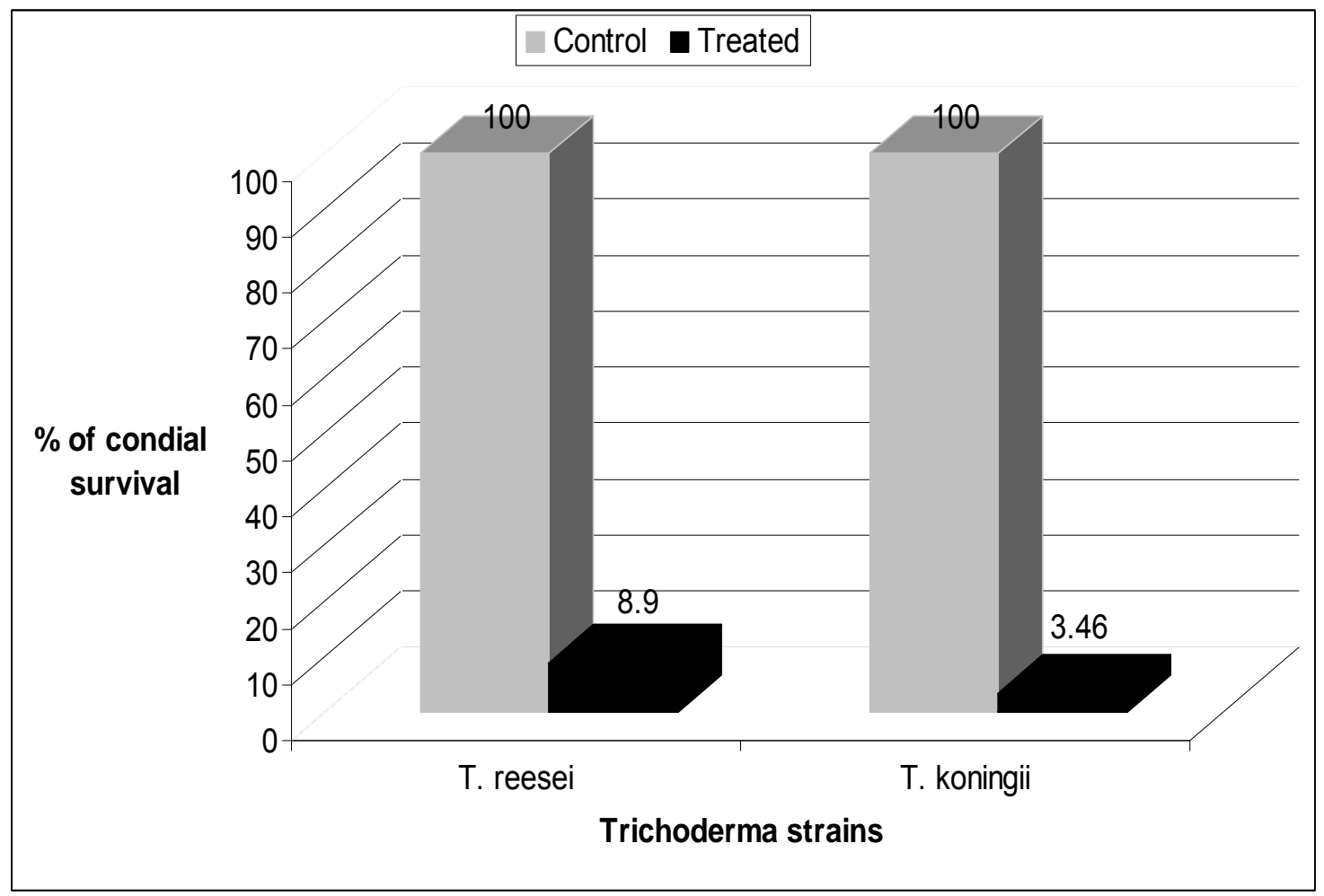

Fig 1. Effect of combination of UV-light and $\mathrm{NaNO}_{2}$ treatment on survival of two Trichoderma species.

Table 1. Mutants obtained after treated Trichoderma species with a combination of UV-light and $\mathrm{NaNO}_{2}$.

\begin{tabular}{l|cc}
\multicolumn{1}{c|}{$\begin{array}{c}\text { Trichoderma } \\
\text { species }\end{array}$} & $\begin{array}{c}\text { No of } \\
\text { mutants }\end{array}$ & $\begin{array}{c}\text { Designated } \\
\text { as }\end{array}$ \\
\hline T. koningii & 3 & Tk-UVN-1, Tk-UVN-2 and Tk-UVN-3 \\
T. reesei & 4 & Tr-UVN-1, Tr-UVN-2, Tr-UVN-3 and Tr-UVN-4 \\
\hline
\end{tabular}

Table 2. Growth, sporulation and antagonistic effect of the two parents ( $T$. koningii and $T$. reesei) and their stable selected mutants against Pythium ultimum after incubation for 6 days at $30^{\circ} \mathrm{C}$.

\begin{tabular}{l|cccc}
\hline \multirow{2}{*}{$\begin{array}{c}\text { Trichoderma species } \\
\text { (Wild type / Mutant) }\end{array}$} & \multicolumn{2}{|c}{$\begin{array}{c}\text { Growth Diameter } \\
(\mathrm{mm})\end{array}$} & $\begin{array}{c}\text { Sporulation } \\
\text { (cfu) }\end{array}$ & $\begin{array}{c}\text { P. ultimum } \\
\text { Growth reduction } \\
\text { (\%) }\end{array}$ \\
\cline { 2 - 3 } & After 4 days & After 6 days & & $46 \mathrm{f}$ \\
\hline T. koningii & $40 \mathrm{~b}$ & $90 \mathrm{a}$ & $250 \times 10^{5}$ & $40.6 \mathrm{~g}$ \\
Tk-UVN-1 & $90 \mathrm{a}$ & $90 \mathrm{a}$ & $1100 \times 10^{5}$ & $99.8 \mathrm{a}$ \\
Tk-UVN-2 & $90 \mathrm{a}$ & $90 \mathrm{a}$ & $1050 \times 10^{5}$ & $63.8 \mathrm{~d}$ \\
Tk-UVN-3 & $90 \mathrm{a}$ & $90 \mathrm{a}$ & $1700 \times 10^{5}$ & $38 \mathrm{~g}$ \\
T. reesei & $28 \mathrm{c}$ & $90 \mathrm{a}$ & $150 \times 10^{5}$ & $58.4 \mathrm{e}$ \\
Tr-UVN-1 & $85 \mathrm{a}$ & $90 \mathrm{a}$ & $500 \times 10^{5}$ & $60.3 \mathrm{de}$ \\
Tr-UVN-2 & $90 \mathrm{a}$ & $90 \mathrm{a}$ & $1010 \times 10^{5}$ & $82.3 \mathrm{~b}$ \\
Tr-UVN-3 & $90 \mathrm{a}$ & $90 \mathrm{a}$ & $1000 \times 10^{5}$ & $98.2 \mathrm{a}$ \\
Tr-UVN-4 & $90 \mathrm{a}$ & $90 \mathrm{a}$ & $1150 \times 10^{5}$ &
\end{tabular}


A

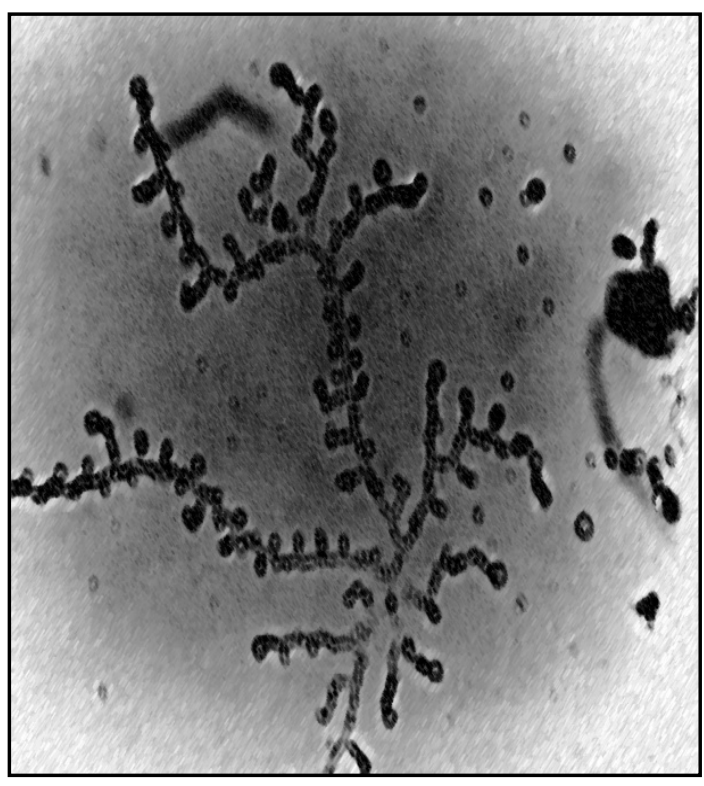

C

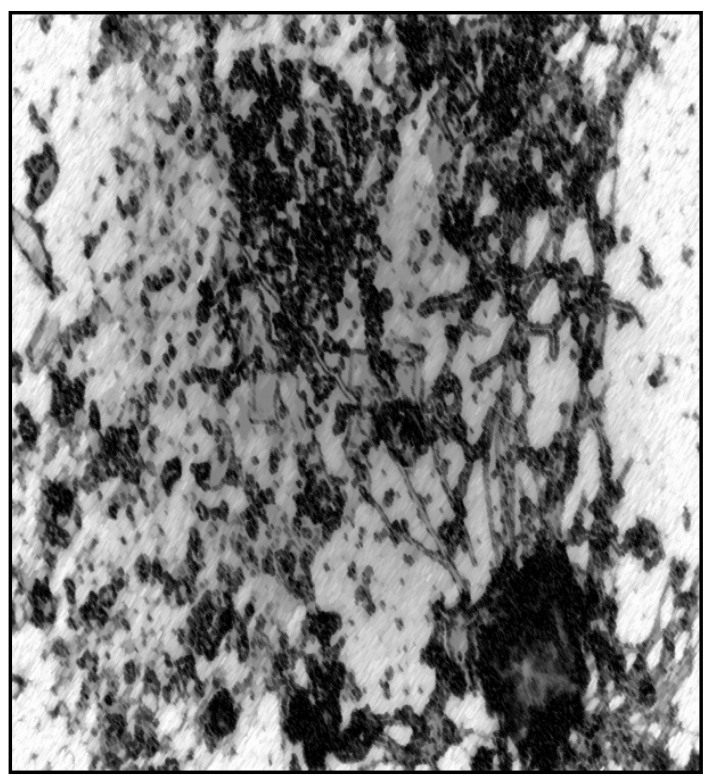

B

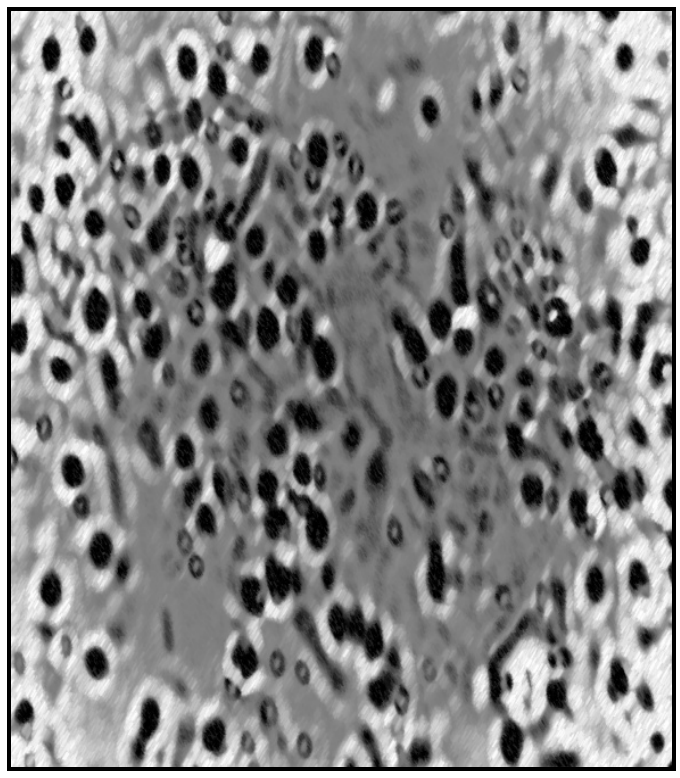

D

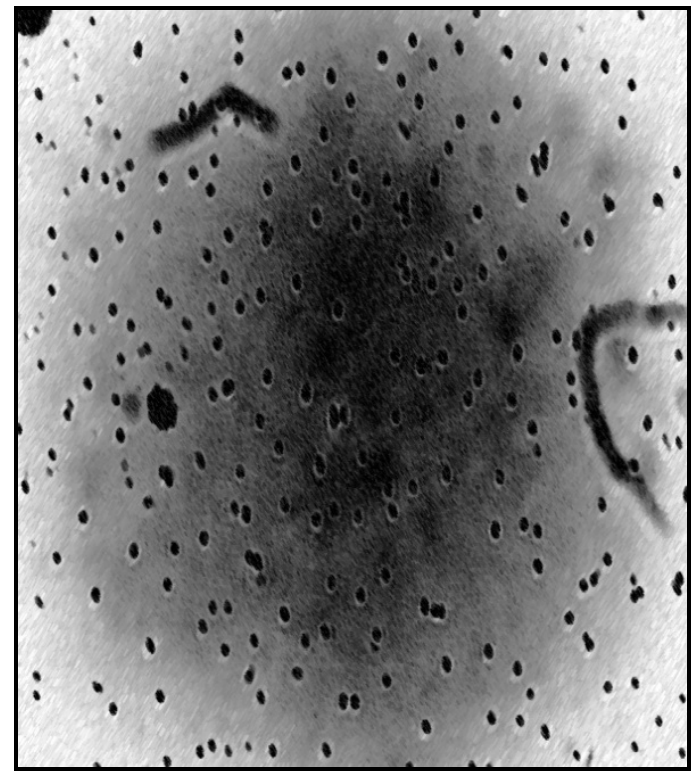

Figure 2. Protoplast formation after lytic enzyme treatment.

A mycelium of $T$. reesei.

${ }^{\mathrm{C}}$ mycelium of $T$. koningii.
${ }^{\text {B }}$ protoplast of $T$. reesei.

${ }^{\mathrm{D}}$ protoplast of $T$. koningii. 
Table 3. Protoplast fusion efficiency

\begin{tabular}{|c|c|c|c|c|c|c|}
\hline $\begin{array}{l}\text { Parental } \\
\text { strains }\end{array}$ & $\begin{array}{l}\text { No. of } \\
\text { starting } \\
\text { conidia / ml }\end{array}$ & $\begin{array}{c}{ }^{\alpha} \text { No. of } \\
\text { protoplast } / \mathrm{ml}\end{array}$ & $\begin{array}{l}\text { No. of } \\
\text { regenerated } \\
\text { protoplasts }\end{array}$ & $\begin{array}{c}{ }^{c} \text { Regeneration } \\
\text { frequency } \\
\%\end{array}$ & $\begin{array}{l}{ }^{\mathrm{D}} \text { No. of } \\
\text { fusants }\end{array}$ & $\begin{array}{c}{ }^{\mathrm{d}} \text { Fusion } \\
\text { frequency } \\
(\%)\end{array}$ \\
\hline $\begin{array}{l}\text { T. koningii } \\
\text { (Tk) }\end{array}$ & $10.0 \times 10^{6}$ & $12.87 \times 10^{5}$ & $5.01 \times 10^{5}$ & $0.06035 \times 10^{5}$ & ----- & ----- \\
\hline $\begin{array}{ll}\text { T. } & \text { reesei } \\
\text { (Tr) } & \end{array}$ & $10.0 \times 10^{6}$ & $11.27 \times 10^{5}$ & $4.39 \times 10^{5}$ & $0.06035 \times 10^{5}$ & ----- & ----- \\
\hline $\begin{array}{l}\text { Fusants } \\
\mathrm{Tk} \times \mathrm{Tr}\end{array}$ & ---- & $12,07 \times 10^{5}$ & ---- & ----- & $\begin{array}{c}6.035 x \\
10^{5}\end{array}$ & $1.25 \pm 0.85$ \\
\hline
\end{tabular}

${ }^{\alpha}$ Protoplasts prepared from strains T. koningii and T. reesei were mixed in almost the same numbers and subjected to fusion treatment as described in the text. They were then placed on the regeneration medium containing Hygromycin and Micanazol as selective agents of strains T. koningii and T. reesei.

${ }^{b}$ The number of colonies that appeared on the regeneration medium was counted as the number of fusants.

${ }^{\mathrm{c}}$ Regeneration frequency measured as no. of fusants $I$ no. of starting conidia.

${ }^{\mathrm{d}}$ Fusion frequency was calculated no. of fusants $I$ no. of starting protoplasts.

Table 4. Reduction of the two Trichoderma species and their selected mutants against pathogens caused root-rot and wilt diseases.

\begin{tabular}{|c|c|c|c|c|}
\hline \multirow{2}{*}{$\begin{array}{l}\text { Trichoderma species } \\
\text { Wild / Mutant }\end{array}$} & \multicolumn{4}{|c|}{ Pathogen } \\
\hline & $\begin{array}{c}F . \\
\text { oxysporum }\end{array}$ & $\begin{array}{c}P . \\
\text { ultimum }\end{array}$ & $\begin{array}{c}S . \\
\text { rolfsii }\end{array}$ & S. sclerotiorum \\
\hline & \multicolumn{4}{|c|}{ Growth reduction (\%) } \\
\hline T. koningii & $52.6 \mathrm{~b}$ & $46 \mathrm{f}$ & $23.3 \mathrm{~g}$ & $55.7 \mathrm{e}$ \\
\hline Tk-UVN-1 & $96.7 \mathrm{a}$ & $40.6 \mathrm{fg}$ & $96.7 \mathrm{a}$ & $99.2 \mathrm{a}$ \\
\hline Tk-UVN-2 & $92.6 \mathrm{a}$ & $99.8 a$ & $98.3 \mathrm{a}$ & $95.4 \mathrm{a}$ \\
\hline Tk-UVN-3 & $58.2 \mathrm{~b}$ & $63.8 \mathrm{~d}$ & $96.7 \mathrm{a}$ & $80.7 \mathrm{bc}$ \\
\hline T. reesei & $46.6 \mathrm{c}$ & $38 \mathrm{~g}$ & $21.7 \mathrm{~g}$ & $35.6 \mathrm{~g}$ \\
\hline Tr-UVN-1 & $98.3 \mathrm{a}$ & $58.4 \mathrm{e}$ & $95.3 \mathrm{a}$ & $98 \mathrm{a}$ \\
\hline Tr-UVN-2 & $96.2 \mathrm{a}$ & $60.3 \mathrm{de}$ & $89 \mathrm{~b}$ & $97.2 \mathrm{a}$ \\
\hline Tr-UVN-3 & $56.7 \mathrm{~b}$ & $82.3 \mathrm{~b}$ & $53.6 \mathrm{e}$ & $73.3 \mathrm{c}$ \\
\hline Tr-UVN-4 & $97.4 \mathrm{a}$ & $98.2 \mathrm{a}$ & $72.3 \mathrm{c}$ & $98 \mathrm{a}$ \\
\hline
\end{tabular}

\# the test was achieved by Dual culture technique.

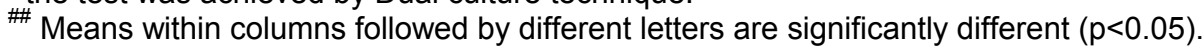

While data in Figures ( $3 \& 4$ ) indicated that, the growth of $F$. oxysporum significantly inhibited on PDA supplemented with $50 \%$ culture filtrate of the mutants ranged from $88.3 \%$ in Tk-UVN-3 to $99.5 \%$ in Tr-UVN-2 compared to their wild type strains, $T$. koningii $(63.4 \%)$ and $T$. reesei $(58.4 \%)$.

The mutants Tk-UVN-2 and Tr-UVN-4 caused the highest reduction rate $99.8 \%$ and $98.2 \%$, respectively against $P$. ultimum growth compared to their wild type strains, T. koningii (46\%) and T. reesei $(38 \%)$ which resulted in a minute growth reduction. Whilst, the other mutants caused reduction rate ranged from $40.6 \%$ (Tk-UVN-1) to $82.3 \%$ (Tr-UVN-4) Table (4). On the other hand the growth of $P$. ultimum was significantly inhibited on PDA supplemented with 50 $\%$ culture filtrate of the selected mutants that ranged from $75.3 \%$ (Tk-UVN-1) to $90.5 \%$ (Tk-UVN-2) compared to their wild type strains, T. koningii (56\%) and $T$. reesei (44\%) Figures (3 \& 4).
The two parent strains $T$. koningii and $T$. reesei caused a minute growth reduction rate of $S$. rolfsii growth reached to 23.3 and $21.7 \%$, respectively. Whilst, the mutants caused the highest reduction rate of S. rolfsii growth ranged between $89 \%$ (Tr-UVN-2) to $98.3 \%$ (Tk-UVN-2) Table (4). On the other hand, the growth of $S$. rolfsii significantly inhibited on PDA supplemented with $50 \%$ culture filtrate of the selected mutants that ranged from $89.3 \%$ (Tk-UVN-1) to $100 \%$ (Tr-UVN-3) compared to their parent strains, T. koningii $(68.6 \%)$ and $T$. reesei $(48.4 \%)$ except mutant Tr-UVN-3 that showed $53.6 \%$ (Figures 3 \& 4).

Also, the two parent strains $T$. koningii and $T$. reesei caused a mediate growth reduction rate of $S$. sclerotiorum reached to 55.7 and $35.6 \%$, respectively. Whilst, the tested mutants caused the highest reduction rate ranged from $73.3 \%$ (Tr-UVN-3) to $99.2 \%$ (Tk-UVN-1) against $S$. sclerotiorum growth 
compared to their parent strains Table (4). On the other hand, the growth of $S$. sclerotiorum significantly inhibited on PDA supplemented with $50 \%$ culture filtrate of the selected mutants ranged between
$84.5 \%$ (Tk-UVN-3) to $92.4 \%$ (Tr-UVN-2) compared to their parent strains $T$. koningii $(67.8 \%)$ and $T$. reesei (64.5\%) Figures (3 \& 4).

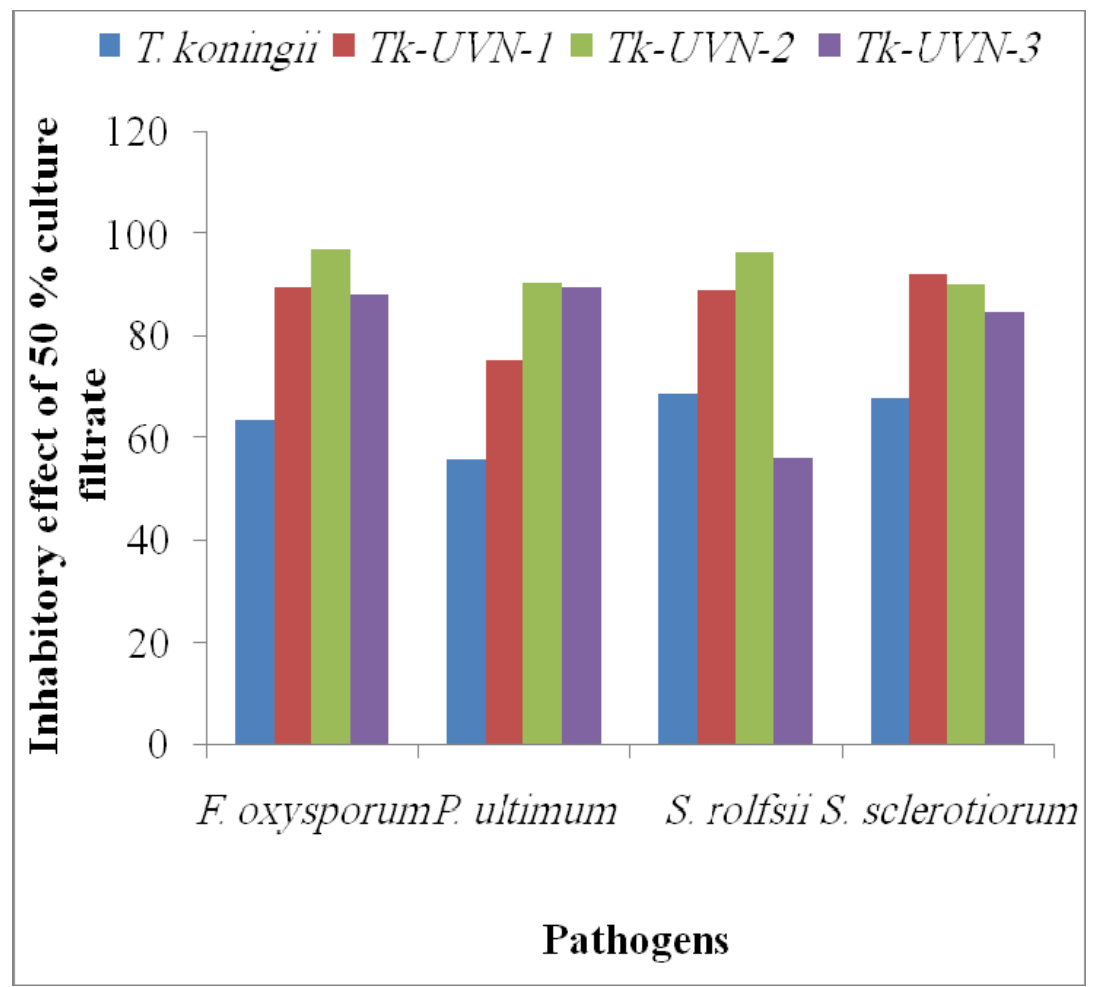

Fig 3. Inhibition of root-rot and wilt diseases pathogens by culture filtrates of $T$. koningii and their selected mutants. \# the test was achieved by Filtrate inhibition technique.

Antagonistic effects of selected fusants against the tested pathogens: Data given in Table (5) showed that the wild type strain T. koningii caused the higher reduction rate against $F$. oxysporum growth than $T$. reesei which resulted in a minute growth reduction. Whilst, the fusants; F2, F3, F5, F8, $\mathrm{F} 12$ and $\mathrm{F} 13$ caused the highest reduction rate that ranged from $96.4 \%$ to $98.6 \%$ against $F$. oxysporum growth compared to their two parents and other fusants that caused growth reduction ranged from $48.2 \%$ (F11) to $90.4 \%$ (F6).

The parent $T$. koningii caused higher reduction rate against $P$. ultimum growth than the other parent $T$. reesei which caused a minute growth reduction. Whilst, the fusants; F3, F4 and F13 caused the highest reduction rate $(94.2,90.4$ and $94.6 \%$, respectively) against $P$. ultimum growth compared to their two parents and other fusants that caused reduction ranged from $36.8 \%$ (F11) to $80.3 \%$ (F5) Table (5).
Also, the parent $T$. koningii caused higher reduction rate against $S$. rolfsii growth than the other parent $T$. reesei which resulted in a minute growth reduction. Whilst, the fusants; F2, F3, F4, F5, F8, F9, F10, F12 and $\mathrm{F} 13$ caused the highest reduction rate ranged between $90.2 \%$ (F13) and $98.2 \%$ (F10) against S. rolfsii growth compared to their two parents and other fusants that caused reduction ranged from $31.8 \%$ (F11) to $80.2 \%$ (F6) Table (5).

At the same trend, the parent $T$. koningii caused higher reduction rate against $S$. sclerotiorum growth than other parent $T$. reesei which showed reduction in a minute growth reduction. Whilst, the fusants; F3, F4, F8 and F13 caused the highest reduction rate ranged between $92.8 \%$ and $99.3 \%$ against $S$. sclerotiorum growth compared to their two parents and other fusants that showed reduction ranged from $45.4 \%$ (F11) to $87.6 \%$ (F2) Table (5). 
Am. J. Sci. Ind. Res., 2010, 1(3): 504-515

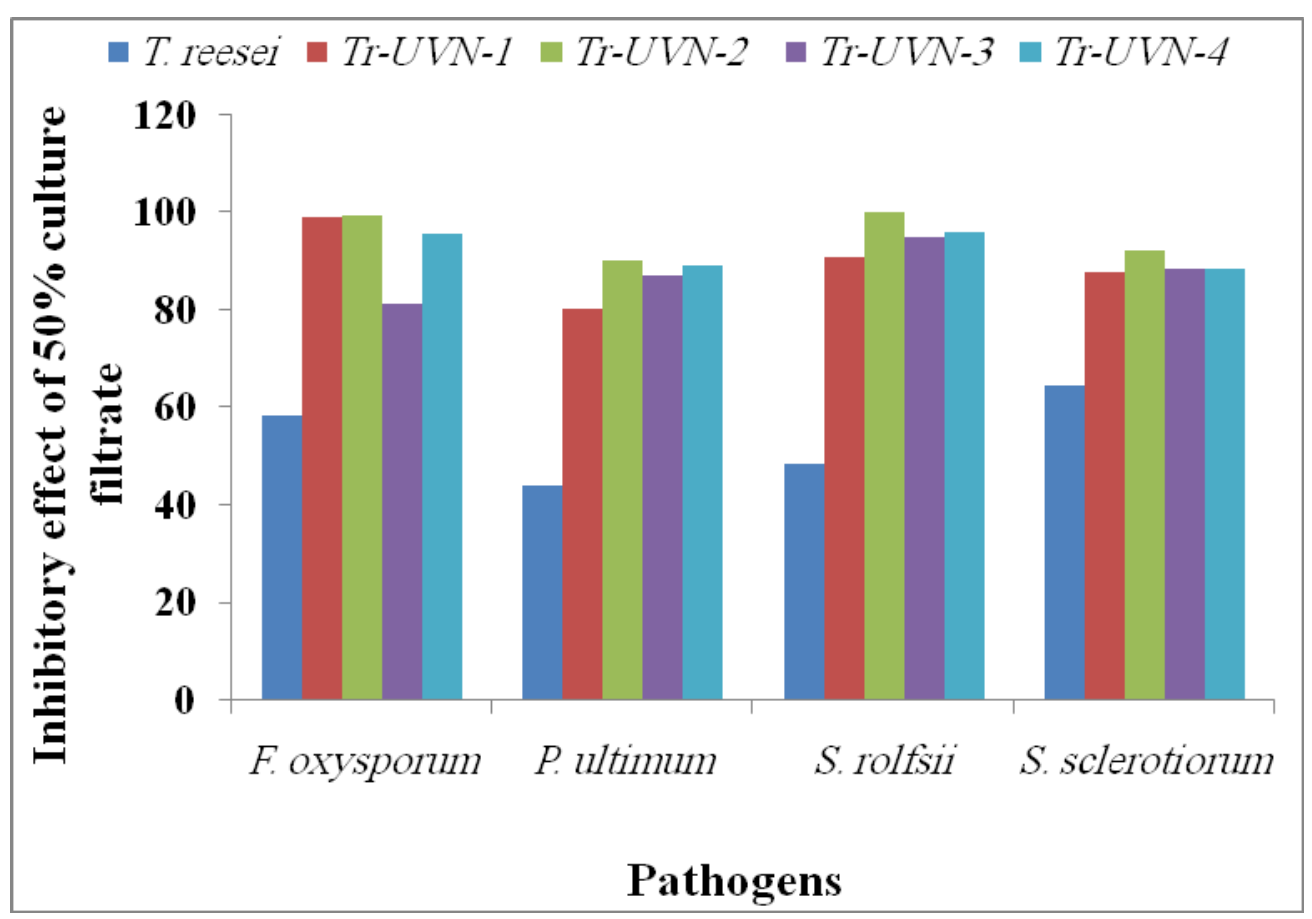

Fig 4. Inhibition root-rot and wilt diseases pathogens by culture filtrate of $T$. reesei and their selected mutants. ${ }^{\#}$ the test was achieved by Filtrate inhibition technique.

Reduction effect of the selected fusants against the tested pathogens:

Table 5. Inhibition of fusants and their parents against root-rot and wilt diseases pathogens.

\begin{tabular}{|c|c|c|c|c|}
\hline \multirow{3}{*}{$\begin{array}{l}\text { Trichoderma } \\
\text { species } \\
\text { Wild / Fusant }\end{array}$} & \multicolumn{4}{|c|}{ Pathogen } \\
\hline & $\begin{array}{c}F . \\
\text { oxysporum }\end{array}$ & $\begin{array}{c}P . \\
\text { ultimum }\end{array}$ & $\begin{array}{c}\mathrm{S} . \\
\text { rolfsii }\end{array}$ & S. sclerotiorum \\
\hline & \multicolumn{4}{|c|}{ Growth reduction (\%) } \\
\hline \multicolumn{5}{|l|}{ Parental strains } \\
\hline T. koningii & $52.6 \mathrm{~cd}$ & $46 \mathrm{e}$ & $23.3 \mathrm{e}$ & $55.7 \mathrm{e}$ \\
\hline T. reesei & $46.6 \mathrm{~d}$ & $38 \mathrm{f}$ & $21.7 \mathrm{e}$ & $35.6 \mathrm{~g}$ \\
\hline Medium & $49.6 \mathrm{~d}$ & $42 \mathrm{e}$ & $22.5 \mathrm{e}$ & $45.65 \mathrm{f}$ \\
\hline \multicolumn{5}{|l|}{ Fusants } \\
\hline F1 & $48.8 \mathrm{~d}$ & $49.4 \mathrm{~d}$ & $71.2 \mathrm{c}$ & $58.6 \mathrm{e}$ \\
\hline F2 & $98.6 \mathrm{a}$ & $38.6 \mathrm{f}$ & 95.8 a & $87.6 \mathrm{~b}$ \\
\hline F3 & $96.4 \mathrm{a}$ & $94.2 \mathrm{a}$ & $97.6 \mathrm{a}$ & $99.3 \mathrm{a}$ \\
\hline F4 & $52.6 \mathrm{~cd}$ & $90.4 \mathrm{a}$ & $90.8 \mathrm{ab}$ & $98.4 \mathrm{a}$ \\
\hline F5 & $98.5 \mathrm{a}$ & $80.3 \mathrm{~b}$ & $92.7 \mathrm{ab}$ & $77.8 \mathrm{c}$ \\
\hline F6 & $90.4 \mathrm{~b}$ & $82.4 \mathrm{~b}$ & $80.2 \mathrm{~b}$ & $78.3 \mathrm{c}$ \\
\hline F7 & $56.4 \mathrm{~cd}$ & $50.2 \mathrm{~d}$ & $33.2 \mathrm{e}$ & $65.4 \mathrm{~d}$ \\
\hline F8 & $98.4 \mathrm{a}$ & $44.8 \mathrm{e}$ & $94.6 \mathrm{ab}$ & $97.5 \mathrm{a}$ \\
\hline F9 & $90.8 \mathrm{~b}$ & $94.6 \mathrm{a}$ & $95.8 \mathrm{a}$ & $86.4 \mathrm{~b}$ \\
\hline F10 & $60.3 c$ & $60.4 \mathrm{c}$ & $98.2 \mathrm{a}$ & $84.7 \mathrm{~b}$ \\
\hline F11 & $48.2 \mathrm{~d}$ & $36.8 \mathrm{f}$ & $31.8 \mathrm{e}$ & $45.4 \mathrm{f}$ \\
\hline F12 & $96.4 \mathrm{a}$ & $60.2 \mathrm{C}$ & $96.4 \mathrm{a}$ & $86.7 \mathrm{~b}$ \\
\hline F13 & $98.4 \mathrm{a}$ & $64.6 \mathrm{c}$ & $90.2 \mathrm{ab}$ & $92.8 \mathrm{a}$ \\
\hline
\end{tabular}

\# the test was achieved by Dual culture technique.

\# Means within columns followed by different letters are significantly different $(p<0.05)$. * Growth on PDA medium as negative control. 
On the other hand, data in data in Table (6) indicated that, the growth of $F$. oxysporum significantly inhibited on PDA supplemented with $50 \%$ culture filtrate of fusants; F2, F3, F5, F8, F10. F12 and F13 ranged from $90.2 \%$ (F8) to $98.4 \%$ (F13) compared to their parent strains, $T$. koningii $(52.6 \%)$ and $T$. reesei $(46.6 \%)$. Whilst, other fusants caused medium inhibition rate against $F$. oxysporum growth ranged from $60.2 \%$ (F11) to $88.2 \%$ (F6), but fusant (F1) caused in a minute growth reduction than their two parents.

Also, the growth of $P$. ultimum significantly inhibited on PDA supplemented with $50 \%$ culture filtrate of the fusants; F3, F4, F9, F10 and F13 ranged from $88.2 \%$ (F4) to $92.4 \%$ (F13) compared to their wild type strains, T. koningii (52.6\%) and T. reesei (46.6\%). Whilst, other fusants caused medium inhibition rate against $P$. ultimum growth ranged from $60.4 \%$ (F8) to $78.6 \%$ (F12), but fusant (F1) caused a minute growth inhibition than its two parents and fusant F11 that caused inhibition rate $\approx$ the parent (Tk) Table (6).
At the same trend, the growth of $S$. rolfsii significantly inhibited on PDA supplemented with $50 \%$ culture filtrate of fusants; F2, F3, F8, F9, F12 and F13 ranged from $90.2 \%$ (F8) to $99.8 \%$ (F13) compared to their parent strains $T$. koningii $(52.6 \%)$ and $T$. reesei $(46.6 \%)$. Whilst, other fusants caused a minute growth inhibition rate ranged from $38.6 \%$ (F6) to $50.2 \%$ (F11), but fusant (F7) caused medium inhibition rate than its two parents also, fusant $(F 5) \approx$ the parent (Tk) and fusant (F10) caused inhibition rate equal the medium of the two parents Table (6).

The data was indicated that, the growth of $S$. sclerotiorum significantly inhibited on PDA supplemented with $50 \%$ culture filtrate of the selected fusants; F3 (95.6\%) and F8 (94.3\%) compared to their wild type strains, T. koningii (52.6\%) and T. reesei (46.6\%). Whilst, other fusants caused medium inhibition rate against $S$. sclerotiorum growth ranged from $72.6 \%$ (F1) to $89.2 \%$ (F12), except fusant F6 (56.8\%) caused inhibition rate $\approx$ the parent (Tk) and fusant F11 (67.5\%) caused a minute growth inhibition than its two parents Table (6).

Table 6. Inhibition of root-rot and wilt diseases pathogens by culture filtrates of the fusants and their parents.

\begin{tabular}{|c|c|c|c|c|}
\hline \multirow{3}{*}{$\begin{array}{l}\text { Trichoderma species } \\
\text { Wild / Fusant }\end{array}$} & \multicolumn{4}{|c|}{ Pathogen } \\
\hline & $\begin{array}{c}F . \\
\text { oxysporum }\end{array}$ & $\begin{array}{c}P . \\
\text { ultimum }\end{array}$ & $\begin{array}{c}\text { S. } \\
\text { rolfsii }\end{array}$ & S. sclerotiorum \\
\hline & \multicolumn{4}{|c|}{ Inhibitory effect of $50 \%$ culture filtrate } \\
\hline \multicolumn{5}{|l|}{ Parental strains } \\
\hline T. koningii & $63.4 \mathrm{~d}$ & $56 \mathrm{e}$ & $68.6 \mathrm{c}$ & $67.8 \mathrm{~d}$ \\
\hline T. reesei & $58.4 \mathrm{~d}$ & $44 \mathrm{f}$ & $48.4 \mathrm{f}$ & 64.5 ef \\
\hline Medium & $60.9 \mathrm{~d}$ & $50 \mathrm{f}$ & $58.5 \mathrm{e}$ & $66.2 \mathrm{e}$ \\
\hline \multicolumn{5}{|l|}{ Fusants } \\
\hline F1 & $54.2 \mathrm{e}$ & $62.4 \mathrm{~d}$ & $43.8 \mathrm{fg}$ & $72.6 \mathrm{~d}$ \\
\hline F2 & $94.8 \mathrm{~b}$ & $66.8 \mathrm{~cd}$ & $98.6 \mathrm{a}$ & $88.3 \mathrm{~b}$ \\
\hline F3 & $98.2 \mathrm{a}$ & $88.6 \mathrm{~b}$ & $92.6 \mathrm{~b}$ & $95.6 \mathrm{a}$ \\
\hline F4 & $76.4 \mathrm{c}$ & $90.8 a$ & $37.6 \mathrm{~g}$ & $82 \mathrm{c}$ \\
\hline F5 & $96.8 a$ & $28.4 \mathrm{~g}$ & $68.4 \mathrm{~d}$ & $85.4 \mathrm{bc}$ \\
\hline F6 & $88.2 \mathrm{~b}$ & $38.4 \mathrm{fg}$ & $38.6 \mathrm{~g}$ & $56.8 \mathrm{f}$ \\
\hline F7 & $66.4 \mathrm{~cd}$ & $60.4 \mathrm{~d}$ & $72.6 \mathrm{c}$ & $77.8 \mathrm{~cd}$ \\
\hline F8 & $90.2 \mathrm{~b}$ & $70.4 \mathrm{c}$ & $90.2 \mathrm{~b}$ & $94.3 \mathrm{a}$ \\
\hline F9 & $96.4 \mathrm{a}$ & $88.4 \mathrm{~b}$ & $95.8 \mathrm{ab}$ & $88.5 b$ \\
\hline F10 & $90.4 \mathrm{~b}$ & $90.4 \mathrm{a}$ & $58.4 \mathrm{e}$ & $74.8 \mathrm{~d}$ \\
\hline F11 & $60.2 \mathrm{~d}$ & $46.8 \mathrm{f}$ & 50.2 ef & $67.5 \mathrm{e}$ \\
\hline F12 & $96.8 \mathrm{a}$ & $78.6 \mathrm{c}$ & $90.8 \mathrm{~b}$ & $89.2 \mathrm{~b}$ \\
\hline F13 & $98.4 \mathrm{a}$ & $92.4 \mathrm{a}$ & $99.8 \mathrm{a}$ & $82.6 \mathrm{c}$ \\
\hline
\end{tabular}

\# the test was achieved by Filtrate inhibition technique.

\#\# Means within columns followed by different letters are significantly different $(p<0.05)$. ${ }^{*}$ Growth on PDA medium without filtrate as negative control.

\section{DISCUSSION}

The present work aimed to apply mutagenesis and protoplast fusion techniques in genetically breeding program of locally isolated $T$. koningii and $T$. reesei to enhancement their biocontrol abilities against several important plant fungal pathogens. Losses due to plant diseases may be as high as $10-20 \%$ of the total worldwide food production every year, resulting in economic losses amounting to many billions of 
dollars and diminished food supplies. Whereas, chemical control involves the use of chemical pesticides to eradicate or reduce the populations of pathogens or to protect the plants from infection by pathogens. For some diseases chemical control is very effective, but it is often non-specific in its effects, killing beneficial organisms as well as pathogens, and it may have undesirable health, safety, and environmental risks [21].

So that biological control involves the use of one or more biological organisms to control the pathogens or diseases. Because biological control is more specialized and uses specific microorganisms that attack or interfere with the pathogens. The members of the genus Trichoderma are very promising against soil-born plant parasitic fungi. These filamentous fungi are very widespread in nature, with high population densities in soils and plant litters. They are saprophytic, quickly growing and easy to culture and they can produce large amounts of conidia with long lifetime [22].

A combination of UV-light and sodium nitrate was used to induce mutation where three and four mutants were isolated from the survivals of the mutagenized $T$. koningii and $T$. reesei strains, respectively (Table 1$)$. After 7 subcultures the stable mutants with important morphological characters (i.e. growth, sporulation and antagonistic effect against $F$. oxysporum, $P$. ultimum, S. rolfsii and S. sclerotiorum) were obtained (Tables $2 \& 4$ ) and (Figures $3 \& 4$ ). This is presumably a consequence of their higher constitutive of metabolites activity. The results are harmonized with many successful attempts used the mutagenesis as tool to enhance the biocontrol efficacy of several Trichoderma Spp. e.g. [8, 12, 13, $18,23,24,25,26,27]$.

The number of protoplast formation from the two parent strains $T$. koningii and $T$. reesei were $12.87 \mathrm{x}$ $10^{5}$ and $11.27 \times 10^{5}$, respectively. But the regeneration frequencies of the two parental strains were $5.01 \times 10^{5}$ and $11.27 \times 10^{5}$, respectively, i.e. regeneration frequency is the rate of grown colonies on CDS to rate of the protoplast formed. Hygromycin and Micanazol were used as selective markers for the tow parental fusion. The efficiency of protoplast fusion between $T$. koningii and $T$. reesei reached $1.25 \%$ (Table 3), i.e. fusion frequency that is the rate of grown colonies on SM to rate of grown colonies on CDS. The resistant behavior of the 13 selected fusants and their parental strains ( $T$. koningii and $T$. reesei) was described. All the selected fusants were resistant to the selective markers (Hygromycin and
Micanazol). The same trend of these results was achieved through protoplast formation isolation, fusion and regeneration of protoplasts from many $T$. harzianum species e.g. $[6,15,28,29,30]$. They reported that protoplast fusion have been achieved in the genus Trichoderma, mainly to enhance its biocontrol potential.

Subjecting the wild types of the collected bioagents Trichoderma spp. to in vitro bioassay found that, $T$. koningii and $T$. reesei were effective in suppressive the tested pathogens; F. oxysporum, P. ultimum, S. rolfsii and $S$. sclerotiorum that cause root-rot and damping-of diseases Tables (5 \& 6). As noted, Trichoderma spp. is used for the control of plant diseases [31]. Also most of the selected mutant (Table 6 and Figures $3 \& 4$ ) or fusants (Tables $5 \& 6$ ) showed superiority in their antagonistic activity against the tested pathogens than their parental strains. In this context [12] reported that the mutagenesis of three Trichoderma species by exhibited high capabilities to produce efficient antibiotics, enzymes and phenols, corresponded to better onion white rot disease control in overall biocontrol ability. Also, Inter and intra hybrids of Trichoderma spp. by protoplast fusion were produced and evaluated of their biocontrol activity against soilborne and foliar pathogens [9, 32, 33].

The antagonism of Trichoderma could be attributed to the competition for nutrients, release of toxic metabolites and extracellular lytic enzymes. Generally, Trichoderma species grow very faster than other fungi [34] and are reported to produce toxic substances like viridin, trichodermin, lytic enzymes, etc. $[35,36]$. The secretion of extracellular enzymes such as chitinase is very well documented and its role on the biological control was established [12, 32, 37].

Conclusion: In conclusion, the superiority in biological control activities of the selected mutants or fusants than their parents ( $T$. koningii and $T$. reesei) against the tested pathogens may be due to the effect of the genetic treatments (i.e. mutagenesis an protoplasts fusion) on their genetic back ground to be varied that allow to change in genetic control of antifungal metabolites production to be more effective. The results indicated that mutation and protoplast fusion techniques are successful tools to enhance the antagonistic effects of Trichoderma species against several fungal plant pathogens. 


\section{REFERENCES}

1. Haggag W.M., Mohamed H.A.A. Biotechnological aspects of microorganisms used in plant biological control (Original articles). American-Eurasian Journal of Sustainable Agriculture. 1(1): 7-12 (2007).

2. Jensen D.F. Research into biological control of root diseases, $17^{\text {th }}$ Denish Plant Protection conference. Horiculure DJ-Rapport Havebru. 12: 37 (2000).

3. Papavizas G.C. Trichoderma and Gliocladum : biology, ecology and potential for biocontrol. Annual Revue Physiopathology. 23: 23-54 (1985).

4. Lumsden R.D., Locke J.C., Adkins S.T., Walter J.F., Ridout C.J. Isolation and localization of the antibiotic gliotoxin produced by Gliocladum virens from Alginate Prill in soil and soil less media. Physiopathology. 82: 230-235 (1992).

5. Michrina J., Michalikova A., Rohacik T., Kulichov R. Antibiosis as possible mechanism of antagonistic action of Trichoderma harzianum against Fusarium culmorum. Ochrana Rostlin. 31: 177-184 (1995).

6. Pecchia S., Anne J. Fusion of protoplast from antagonistic Trichoderma harzianum strains. Acta Horticulture. 255: 303-311 (1989).

7. Mukherjee P.K., Phytopath Mukhopadhyay A.N. Induction of stable mutants of Gliocladum virens by gamma-irradiation. Indian. 46: 393-397 (1993).

8. Gadgil N.J., Daginawala H.F., Chakrabarti T., Khanna P. Enhanced cellulose production by a mutant of Trichoderma reesei. Enzyme and Microbial Technology. 17: 942-946 (1995).

9. Migheli Q., Whipps J.M., Budge S., Lynch J. Production of inter and intra hybrids of Trichoderma spp. by protoplast fusion and evaluation of their biocontrol activity against soil-borne and foliar pathogens. J. Physiopathology. 143: 91-97 (1995).

10. Mukherjee P.K., Sherkhane P.D., Muthy, N.B. Induction of stable Benomyl-tolerant phenotypic mutants of Trichoderma pseudokoningii MTCC 3011, and their evaluation for antagonistic and biocontrol potential. Indian J. Exp. Biol. 37: 710-712 (1999).

11. Rey M., Delgado J.J., Rincon A.M., Limon C.M., Benitez T., Perez E.A., Cantoral, F. J. Improvement of Trichoderma strains for biocontrol. Micologia industrial Y Micopatotogia, 17: 531-536 (2000).

12. Haggag, W.M., Mohamed H.A.A. Enhancement of antifungal metabolites production from gamma-ray induced mutants of some Trichoderma species for control onion white rot disease. Plant Pathology Bulletin (China). 11:45-56 (2002).

13. Haggag W.M., Mohamed H.A.A. Attallah A.G. Genetic enhancement of Trichoderma viride to overproduce different hydrolytic enzymes and their biocontrol potentiality against root rot and white mold diseases in bean plants. Agriculture and Biology Journal of North America. 1(3): 273-284 (2010).

14. Stasz, T.E. Genetic improvement of fungi by protoplast fusion for biological control of plant pathogens. Can $\mathrm{J}$ Plant Pathol. 12: 322-327 (1990).

15. Sivan A. Harman G.E. Improved rhizosphere competence in a protoplast fusion progeny of Trichoderma harzianum. J Gen Microbiol. 137: 23-30 (1991)

16. Pe'er S., Chet I. Trichoderma protoplast fusion: A tool for improving biocontrol agents. Can J Microbiol. 36: 6-9 (1990).

17. Abd El-Zaher F.M., Fadel M. Production of bioethanol via enzymatic scarification of rice straw by cellulase produced by Trichoderma reesei under solid state fermentation. New York Science Journal. 3(4): 72-78 (2010).

18. Mohamed H.A.A. Haggag W.M. Biocontrol potential of salinity tolerant mutants of Trichoderma harzianum against Fusarium oxysporum, causing tomato wilt disease. Brazilian J. Microbiology 37: 175-185. (2006).

19. Mohamed H.A. A., Haggag W.M. Genetically Improving the Antifungal Activity and Antibiotic Production by Gliocladium Strains. Plant Biotechnology Bulletin (NRC). 3: 29-36 (2005).

20. Kirimura K., Yaguchi T., Usami S. Intraspesfic protoplast fusion of citric acid-producing strains of Aspergillus niger. J. Ferment Tchnol. 64: 473-479 (1986)

21. Manczinger L., Antal Zs., Kredics L. Ecophysiology and breeding of mycoparasitic Trichoderma strains (a review). Acta Microbiologica et Immunologica Hungarica. 49 (1): 1-14 (2002).

22. Samuels G.J. Trichoderma: a review of biology and systematic of the genus. McCool Res. 100: 923-935 (1996).

23. Chernolazov V.M., Ermolora O.V., Uozn U.V., Klyosov A.A. A Method for detection of cellulases in polyacrylamid gels using 5-bromoindoxyl-Bcellobioside high sensitively and resolution. Annal. Bioch. 182: p. 250 (1989)

24. Rajappan K., Raguchander T., Manickam K. Efficacy of UV-induced mutants of Trichoderma viride against Sclerotum rolfsii. Plant Dis. Res. 11: 97-99 (1996).

25. Melo I.S., Faull J.L., Graeme-Cook K.A. Relationship between in vitro cellulase production of UV-induced mutants of Trichoderma harzianum and their been rhizosphere competence. Mycol. Res. 101: 1389-1392 (1997).

26. Kumar A., Gupta J.P. Alteration in the antifungal metabolite production of tebuconazole tolerant mutants 
of Trichoderma viride. Acta Physiopathology Entomotogica Hungarica. 34: 27-34 (1999).

27. Youssef B.M., Aziz, N.H. Influence of gamma-irradiation on the bioconversion of rice straw by Trichoderma viride into single cell protein. Cytobios. 97:171-183 (1999).

28. Ogawa K., Ohara H., Koide T., Toyama N. Interspecific hybridization of Trichoderma reesei by protoplast fusion. J. Ferment. Bioeng. 67: 207-209 (1989).

29. Mrinalini C., Lalithakumari D. Integration of enhanced biocontrol efficacy and fungicide tolerance in Trichoderma spp. by electrofusion. J. Plant Dis. Prot. 105: 34 - 40 (1998).

30. EL-Bondkly A.M, Talkhan F. N. Intra-strain crossing in Trichoderma harzianum via protoplast fusion to enhance chitinase productivity and biocontrol activity. Arab J. Biotech. 10(2): 233.240 (2007).

31. Esposito E., da Silva M. Systematic and environmental application of the genus Trichoderma. Critical Reviews in Microbiology. 24: 89-98 (1998).
32. Sivan A., Chet I. Microbial control of plant diseases. In: Mitchell, R. (ed.) Environmental Microbiology. WileyLiss Inc., New York. p. 335 (1992).

33. Hanson L.E., Howell C.R. Biocontrol efficacy and other characteristics of protoplast fusants between Trichoderma koningii and T. virens. Mycological Research. 106: 321-328 (2002).

34. Mathivanan N., Srinivasan K., Chelliah S. Biological control of soil-borne diseases of cotton, eggplant, okra and sunflower by Trichoderma viride. J. Plant Dis. Prot. 107: 235 - 244 (2000).

35. Weindling R. Experimental Physiopathology. Physiopathology. 31: 991-1003 (1941).

36. Weindling R., Emerson O.H. The isolation of a toxic substance from the culture of Trichoderma. Physiopathology. 26: 1068-1070 (1936).

37. Prabavathy V.R., Mathivanan N., Sagadevan E., Murugesan K., Lalithakumari D. Intra-strain protoplast fusion enhances carboxymethyl cellulase activity in Trichoderma reesei. Enzyme Microb. Technol. 38: 719723 (2006). 